\title{
Wood anatomy of Laguncularia racemosa (Combretaceae) in mangrove and transitional forest, Southern Brazil
}

\author{
Adriana Jantsch ${ }^{1}$, João Carlos Ferreira de Melo Júnior ${ }^{1}$, Maick Willian Amorim¹, \\ Letícia Larcher ${ }^{2} \&$ Patrícia Soffiatti ${ }^{3 *}$ \\ 1. Universidade da Região de Joinville, Departamento de Ciências Biológicas, Laboratório de Anatomia e Ecologia \\ Vegetal - Rua Paulo Maschitzki, 10, CEP 89219-710, Joinville, SC, Brasil; jcmelo_wood@hotmail.com \\ 2. Universidade da Região de Joinville, Departamento de Ciências Biológicas, Laboratório de Anatomia e Ecologia \\ Vegetal, 171. CEP 79300-010, Corumbá, MS, Brasil; leticialarcher@gmail.com \\ 3. Universidade Federal do Paraná, Programa de Pós-Graduação em Botânica, Departamento de Botânica, SCB, Centro \\ Politécnico, Caixa Postal 19031, Curitiba, PR. Brazil, CEP 81.531-880; psoffiatti.ufpr@gmail.com \\ * Correspondence
}

Received 12-VI-2017. Corrected 12-III-2018. Accepted 10-IV-2018.

\begin{abstract}
Mangroves represent an environment of great heterogeneity and low diversity of plant species that have structural and physiological adaptations linked to a high salinity environment. Laguncularia racemosa is a typical tree species in mangroves and transitional zones. This study aimed to compare the wood anatomy of $L$. racemosa (Combretaceae) in two different forests (mangroves and transitional forests), which have different soil conditions. For this, we obtained wood and soil samples in March 2016. We analyzed soil nutritional contents in one $15 \mathrm{~cm}$ deep soil sample per forest type. In addition, we selected five mangrove trees in each formation for wood anatomy analysis and took one wood sample per individual, per area. We prepared histological slides and separated materials following standard methods for wood anatomy studies. Soil analysis showed that mangrove soils had higher phosphorus, potassium and calcium contents. The transitional soil had lower pore water salinity and soil $\mathrm{pH}$, probably due to high aluminum levels. Anatomical attributes differed between different forest populations. In the different wood aspects evaluated, we obtained higher values in mangrove individuals when compared to the transitional forest population: vessel elements length $(375.79 \mu \mathrm{m})$, tangential vessels diameter $(75.85 \mu \mathrm{m})$, frequency of vessels $(11.90 \mu \mathrm{m})$ and fiber length $(889.89 \mu \mathrm{m})$. Moreover, parenchyma rays height was larger in the samples of the transitional forest $(392.80 \mu \mathrm{m})$, while the mangrove population presented wider rays $(29.38 \mu \mathrm{m})$. The structure of the secondary xylem in the studied species apparently responds to edaphic parameters and shows variations that allow it to adjust to the environmental conditions. The population of the transitional forest showed a secondary xylem that invests more in protection than the mangrove population. Rev. Biol. Trop. 66(2): 647-657. Epub 2018 June 01.
\end{abstract}

Key words: ecological wood anatomy; salinity; white mangrove; wood plasticity.

Mangroves are coastal ecosystems in the transition areas between marine and terrestrial environments, of well-known ecological, economic and social importance (Madi, Boeger, \& Reissmann, 2015). Mangroves occur in tropical and subtropical regions. They constitute authentic coastal forests, in which plant structure and ecology are highly adapted to topographic and geomorphological differences, saline fluctuations and tidal amplitudes (Santos et al., 2012). Mangroves forests may cover estuarine areas, bays, inlets, river mouths, lagoons, or simply be exposed to the coastline (Schaeffer-Novelli, 1995).

The diversity of mangrove tree species is extremely low when compared to other tropical ecosystems. It comprises ca. 54 plant species considering mangroves worldwide distribution 
(Tomlinson, 1986). In Brazil, seven tree species are present, and belong to the Rhizophoraceae, Acanthaceae and Combretaceae families (Schaeffer-Novelli, Cintron-Molero, Adaime, \& Camargo, 1990). Specific to its Southernmost distribution, only three tree species compose mangroves forest in Southern Brazil: Avicennia schaueriana Stapf \& Leachman (Acanthaceae), Laguncularia racemosa (L.) Gaertn (Combretaceae) and Rhizophora mangle L. (Rhizophoraceae) (Schaeffer-Novelli et al., 1990; Kilca, Alberti, Souza, \& Wolff, 2011; Soares, Tognella, Cuevas, \& Medina, 2015).

Along the Brazilian coast, mangrove forests have different structure and species distribution (Lima \& Tognella, 2012). For example, although $L$. racemosa distribution ranges over the coast, its representativeness is greater in Southern mangroves (Schaeffer-Noveli et al., 1990). Usually, L. racemosa can be found in open areas, as well as in transitional areas of restinga and lowland forests (Bernini \& Rezende, 2003). The transitional forests are less affected by tides regime and are subject to less frequent flooding_located inland (EMBRAPA, 2013).

Despite of its high primary production (Ball, 1996), mangroves are stressful environments to plant development due to high water salinity influenced by periodic tidal flooding, low oxygenation, and unconstrained soil (Lüttge, 2008). The vegetation associated to this ecosystem has specific adaptations to establish and thrive in halophytic environments (Krauss, Lovelock, McKee, López-Hoffman, Ewe, \& Sousa, 2008), resulting in a set of adaptations in their structural, ecophysiological and functional characteristics (Pascoalini, Falqueto, \& Tognella, 2014; Larcher, Boeger, \& Sternberg, 2016).

Mangrove tree species may present three different mechanisms to cope with high salinity and to control salt concentration in their tissues (Parida \& Jah, 2010). L. racemosa shows an ecophysiological mechanism of salt exclusion, which may be associated with a wide range of tolerance to salinity: L. racemosa occurs at contrasting salinities, in areas of salinity close to fresh water towards salt water (Sobrado, 2005). This mechanism is also reflected in its morphological and anatomical adaptations. For example, Bartz, Melo Jr., and Larcher (2015) suggests mangrove individuals are smaller, with lower trunk diameter height and crown density and higher leaf area, than individuals of transitional forests.

The high evaporative demand combined with the vulnerability to embolism or cavitation, due to the high concentration of ions in the environment, were previous associated to adaptations in the secondary xylem of mangrove species (Lovelock et al., 2007; Krauss et al., 2008). At high salinity, the low soil water potential requires a decrease in the plant water potential to maintain water uptake by roots, leading plants to decrease water conductivity in secondary xylem (Reef \& Lovelock, 2015). The anatomical characteristics and, consequently, the physical-mechanical properties of this tissue, is affected by environmental variations (Baas, Wheeler, \& Fahn, 1983; Carlquist, 2001; Marcati, Angyalossy-Alfonso, \& Benetati, 2001; Cosmo, Kuniyoshi, \& Botosso, 2010).

We expected mangroves species, as $L$. racemosa, to express several secondary xylem phenotypes in response to variation of environmental factors, such as precipitation, temperature and water availability. Thus, this study aimed to evaluate the wood anatomy of $L$. racemosa populations occurring in mangrove and transitional forests between mangrove and restinga forest. We hypothesize that mangrove individuals may have anatomical adaptations to deal with higher pore water salinity and lower soil water potential, while transition mangroves are less conservative in water use.

\section{MATERIAL AND METHODS}

Study area: The Caieira Municipal Natural Park was located in the center-east portion of the city of Joinville/SC, Brazil (Fig. 1). Inside the park, there was the Lagoa of Saguaçu $\left(26^{\circ} 18^{\prime} 24^{\prime \prime} \mathrm{S}-48^{\circ} 47^{\prime} 36^{\prime \prime} \mathrm{W}\right)$, with approximately $1000 \mathrm{~km}^{2}$ of mangrove remnants and transitional forest, from mangrove towards 

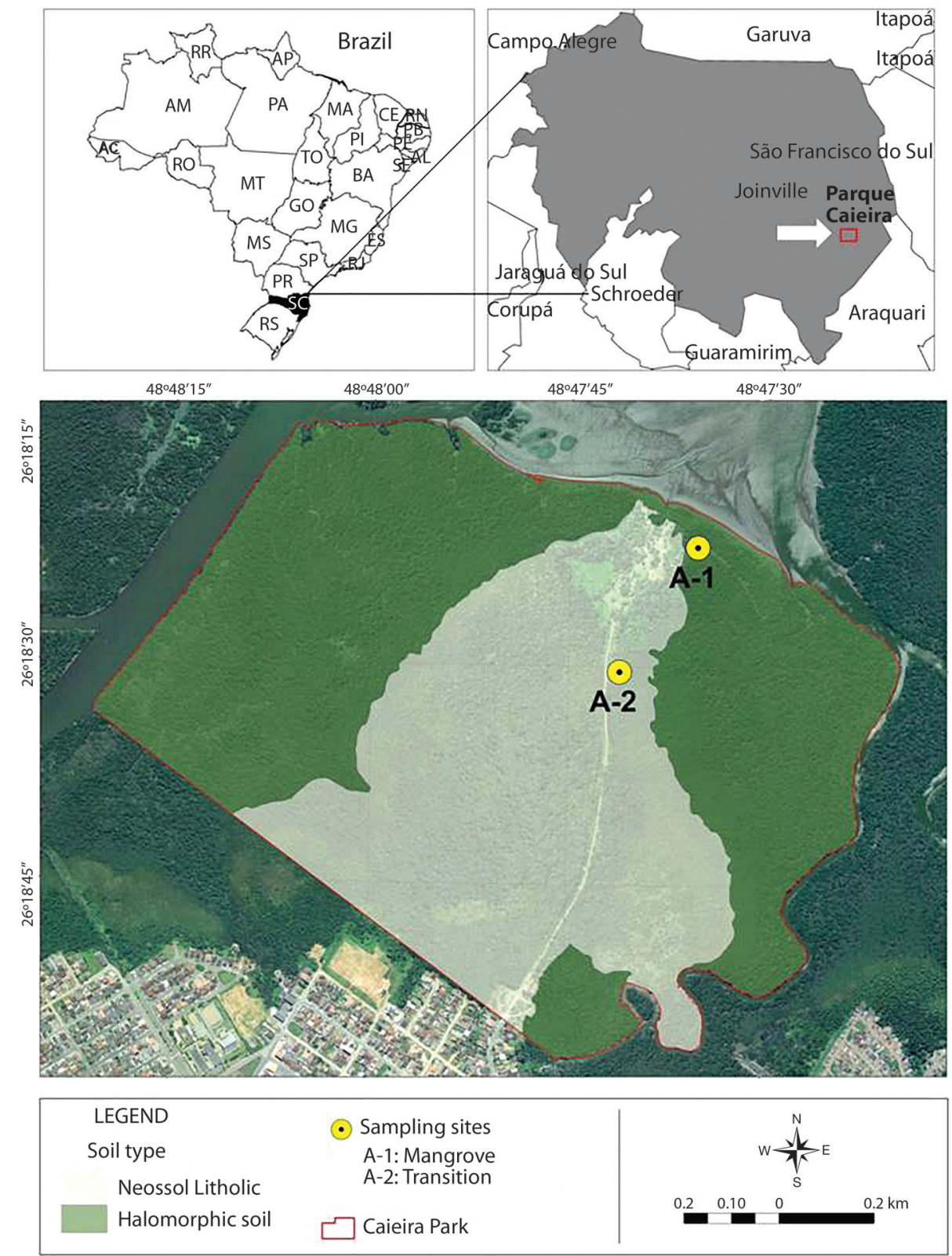

Fig. 1. Study area inside the Caieira Municipal Natural Park, Joinville, Santa Catarina, Brazil: Mangrove forest (A-1) and transitional forest (A-2) (located between lat $-26^{\circ} 18^{\prime} 15^{\prime \prime} /-26^{\circ} 18^{\prime} 30^{\prime \prime}$ and long $\left.-48^{\circ} 48^{\prime} /-48^{\circ} 47^{\prime} 30^{\prime \prime}\right)$.

restinga and lowland forest. The transitional forest occured between the mangrove zone and restinga forest; is not directly subject to the tides regime (not frequently flooded), and is characterized by the presence of the species Talipariti tiliaceum (L.) Fryxell
(Malvaceae) as a schrub (EMBRAPA, 2013). L. racemosa had high absolute density in both mangrove and transitional forests.

The holomorphic soils of mangrove forests were developed by the deposition of marine and fluvial sediments, with the presence of 
organic matter, under constant influence of the sea. Usually, mangrove soils occur in regions of flat topography in the coastal strip. The soil of the transitional forest was a Neosoil composed by thin organic material or mineral material (EMBRAPA, 2013).

The climate is hot and temperate ( $\mathrm{Cfa}$ in the Köeppen and Geiger classification), with average annual temperature around $21.1^{\circ} \mathrm{C}$ and with $1706 \mathrm{~mm}$ annual rainfall to the year of 2016 (Climate-Data, 2016). The sampling period $(\mathrm{March} / 2016)$ corresponded to the end of the summer season, with average temperature of $24.1^{\circ} \mathrm{C}$ and a mean precipitation of $204 \mathrm{~mm}$.

Soil analysis: In both formations, we evaluated soil chemical characterization from one composed sample, collected $15 \mathrm{~cm}$ deep and homogenized, according to the methodology proposed by EMBRAPA (2013). We performed soil characterization using the Soil Analysis Laboratory (LAS) of the Agricultural Research and Rural Extension Company of Santa Catarina (Epagri), considering nutritional status and texture (EMBRAPA, 2013). We collected interstitial water using a sterile collecting device after digging holes into the soil of both study areas with the aid of a hollow tube. The salinity was measured using a refractomer (Vodex). The collections took place in March/2016.

Wood analysis: A total of ten wood samples - one sample per tree, from the outer wood region (close to the vascular cambium) - from mature populations, were taken at breast height (1.30 $\mathrm{m}$ high) from five individuals per population, during low tide following the Tides Tables (Epagri/Ciram, 2014), on the same period of March of 2016, which corresponded to the driest period of the year. Mature individuals were defined as adult trees which have been through reproductive periods. In the mangrove area, individuals were sampled near the fringe. Samples were registered in the Wood Library JOlw under the numbers JOlw 1129 to 1138 (collection number JCM 1401 to 1409 and 1010) for mangrove samples and JOlw 1119 to 1128 (collection number JCM 1411 to 1419 and 1020) for transitional mangroves samples.

Wood samples of $3 \mathrm{~cm}^{3}$ were used for histological preparation accordingly to standard techniques in wood anatomy (Johansen, 1940). We softened wood samples through cooking in glycerinated water $30 \%$ (Ferreirinha, 1958). To obtain permanent histological slides, histological sections were made in transverse, tangential longitudinal and radial longitudinal sections planes (Johansen, 1940). Then, sections were clarified in sodium hypochlorite, washed in distilled water, stained with Safrablau (Bukatsch, 1972) and dehydrated in increasing ethyl series (Kraus \& Arduim, 1997). We prepare slides using stained glass synthetic resin (Vasconcelos, MilanezeGutierre, \& Inada, 2006).

Descriptions terminology followed the recommendations of the IAWA List of Microscopic Features for Harwood Identification (IAWA Committee, 1989). Thirty measurements of wood attributes were measured: tangential diameter $(\mu \mathrm{m})$ and vessel frequency $\left(\mathrm{n} / \mathrm{mm}^{2}\right)$, vessel and fiber length $(\mu \mathrm{m})$, fiber wall thickness $(\mu \mathrm{m})$, height and width (number of cells and $\mu \mathrm{m}$ ).

We calculated mean values and standard deviations for all anatomical attributes. We compared mean values by Student's t-test, with a significance level of $5 \%$, in "R" (R Development Core Team, 2011) with the "labdsv" package (Roberts \& Roberts, 2007), following the normality test and homogeneity of variance when necessary.

\section{RESULTS}

Soil analysis: Mangrove soils showed higher values for porewater salinity $(5.05 \%)$ and higher $\mathrm{pH}$ (6.4), phosphorus (50 mg. $\left.\mathrm{dm}^{-3}\right)$, potassium $\left(142 \mathrm{mmol}_{\mathrm{c}} \cdot \mathrm{dm}^{-3}\right)$, calcium (291 $\left.\mathrm{mmol}_{\mathrm{c}} \cdot \mathrm{dm}^{-3}\right)$ and sodium $\left(685 \mathrm{mg} \cdot \mathrm{dm}^{-3}\right)$ contents, base sum $\left(422.4 \mathrm{mmol}_{\mathrm{c}} \cdot \mathrm{dm}^{-3}\right)$ and base saturation percentage $(96.46 \%)$. The soil of the transitional forest presented lower porewater salinity $(0.68 \%)$ and $\mathrm{pH}(3)$, probably due to the higher amount of aluminum $\left(6.3 \mathrm{mg} \cdot \mathrm{dm}^{-3}\right)$ and exchangeable cations (1 $\left.100 \mathrm{mmol}_{\mathrm{c}} \cdot \mathrm{dm}^{-3}\right)$, expressed by the cation exchange capacity 
(1 $\left.100 \mathrm{mmol}_{\mathrm{c}} \cdot \mathrm{dm}^{-3}\right)$, and the aluminum saturation (863.4 $\mathrm{mmol}_{\mathrm{c}} \cdot \mathrm{dm}^{-3}$; Table 1). Both areas presented the same amount of magnesium $\left(97 / 95 \mathrm{mmol}_{\mathrm{c}} \cdot \mathrm{dm}^{-3}\right)$, organic matter $(10 \%)$ and boron $\left(1.24 / 1.22 \mathrm{mg} . \mathrm{dm}^{-3}\right)$.

Wood anatomical description (Fig. 2): L. racemosa presented indistinct growth rings and diffuse porous wood, without specific vessel arrangement. Vessels were solitary and multiples of 2 to 3, rare 4-5, with simple perforation plate. Bordered intervessel pits were alternate; radio-vessel bordered pits were larger than the intervessel pits. Fibres had minute to simple bordered pits; layers of thin-walled fibres alternate with layers of thick-walled fibres. Axial paratracheal parenchyma was aliform lonsangular to confluent; starch grains were present in the axial parenchyma. Rays were heterogeneus and uniseriate, with body composed of procumbent cells, and margins of erect and squared cells.

Regarding quantitative data, populations of $L$. racemosa presented differences for all studied wood anatomical parameters, except for mean fiber wall thickness (Table 2, Fig. 3). Mangrove population had the highest values for mean vessel diameter, length and frequency, ray width and fiber length. The transitional forest population had the mean higher rays. Mean fiber wall thickness was equal in both populations.

\section{DISCUSSION}

The higher variation of sodium content between the areas can be explained by the proximity to salty waters (Prada-Gamero, VidalTorrado, \& Ferreira, 2004). Sodium is one of the cations associated to saline soils (Maksimovic \& Ilin, 2012). The transitional forest area is not directly affected by salty water flooding, so its concentration of calcium was lower than in mangrove area. Another cation directly affected by salinity is calcium, which presents higher concentrations in more saline soils (Maksimovic \& Ilin, 2012). In higher salinity soils with unconstrained sediments, calcium may act as a secondary messenger in cellular processes adjustments (Madi et al., 2015).

TABLE 1

Soil properties (mean values, $\mathrm{n}=5$ ) of mangrove and transitional forest at the Caieira Municipal Natural Park, Joinville, Santa Catarina, Brazil

\begin{tabular}{|c|c|c|}
\hline Soil properties & Mangrove & Transitional \\
\hline Porewater Salinity (\%) & 5.05 & 0.68 \\
\hline Clay percentage $(\%)$ & 11 & 9 \\
\hline $\mathrm{pH}$ & 6.4 & 3 \\
\hline SMP index & 6.9 & 3.4 \\
\hline Phosphorus content (mg.dm ${ }^{-3}$ ) & 50 & 16.1 \\
\hline Potassium content $\left(\mathrm{mmol}_{\mathrm{c}} \cdot \mathrm{dm}^{-3}\right)$ & 142 & 10 \\
\hline Organic matter $(\%)$ & 10 & 10 \\
\hline Aluminum content $\left(\mathrm{mg} \cdot \mathrm{dm}^{-3}\right)$ & 0.3 & 6.3 \\
\hline Calcium content $\left(\mathrm{mmol}_{\mathrm{c}} \cdot \mathrm{dm}^{-3}\right)$ & 291 & 122 \\
\hline Magnesium content $\left(\mathrm{mmol}_{\mathrm{c}} \cdot \mathrm{dm}^{-3}\right)$ & 97 & 95 \\
\hline Sodium content $\left(\mathrm{mg} \cdot \mathrm{dm}^{-3}\right)$ & 685 & 471 \\
\hline $\mathrm{H}+\mathrm{Al}\left(\mathrm{mmol}_{\mathrm{c}} \cdot \mathrm{dm}^{-3}\right)$ & 15.5 & 863.4 \\
\hline Sum of bases $\left(\mathrm{mmol}_{\mathrm{c}} \cdot \mathrm{dm}^{-3}\right)$ & 422.4 & 238.4 \\
\hline Cation exchange capacity $\left(\mathrm{mmol}_{\mathrm{c}} \cdot \mathrm{dm}^{-3}\right)$ & 437.9 & 1100 \\
\hline Bases saturation $(\%)$ & 96.46 & 21.64 \\
\hline Sulfur content $\left(\mathrm{mg} \cdot \mathrm{dm}^{-3}\right)$ & 0.11 & 0.51 \\
\hline Boron content $\left(\mathrm{mg} \cdot \mathrm{dm}^{-3}\right)$ & 1.24 & 1.22 \\
\hline
\end{tabular}



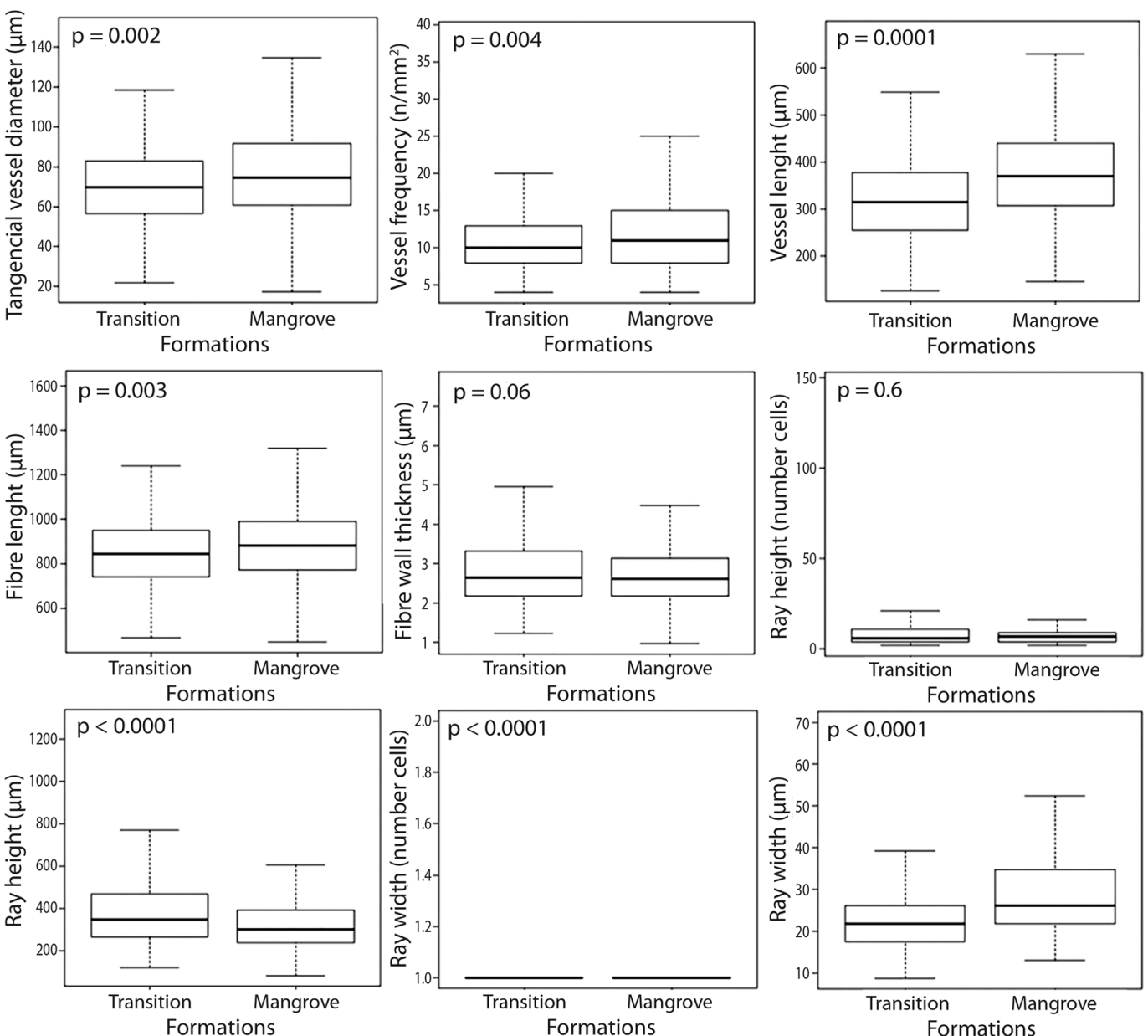

Fig. 2. Comparative wood anatomy of Laguncularia racemosa (Combretaceae). A - B: cross section showing vessel diameter and vessel frequency in mangrove (A) and transitional forest (B). C - D: radial section showing height and width of rays in mangrove $(\mathrm{C})$ and transitional forest (D). E: vessel length in mangrove $(\mathrm{Mg})$ and transitional forest (Tr). F: fiber height in mangrove $(\mathrm{Mg})$ and transitional forest $(\mathrm{Tr})$. Scale bars $=100 \mu \mathrm{m}$.

The porewater salinity, linked to tides dynamics, vary between areas closer to the salt water or to the restinga forest (Kathiresan \& Bingham, 2001). Soils cation exchange capacity in mangroves is correlated to the flooding amplitude and tide duration (Ukpong, 2000; Naidoo, 2010; Urrego, Molina, \& Suárez, 2014), resulting in salinity gradients and ions concentration along the flooding plateau. Both population samples were collected in the dry season, in low tides, and in the transitional forests floodings are less frequent and the influence of tides is low.
We found lower values of $\mathrm{pH}$ in the transitional area, which may influence the availability of nutrients (Ukpong, 2000; Krauss et al., 2008; Lima \& Tognella, 2012). It is known that the $\mathrm{pH}$ changes the availability of important nutrients such as phosphorus, and non-essential like aluminium (Hossaim \& Nuruddin, 2016). This situation was observed in the mangrove study area, where we found most of the nutrients in higher concentration and the $\mathrm{pH}$ is near to neutral. On the other hand, phosphorus is one nutrient highly sensitive to $\mathrm{pH}$ variation, in more acidic or alkaline soils, phosphorus tends 
TABLE 2

Mean values and standard deviation of wood attributes of Laguncularia racemosa

(Combretaceae) populations in mangrove and transitional forest populations of

the Caieira Municipal Natural Park, Joinville, Santa Catarina, Brazil $(n=30)$

\begin{tabular}{lcc}
\multicolumn{1}{c}{ Atributes } & Mangrove & Transitional \\
Vessel diameter $(\mu \mathrm{m})$ & $75.85 \pm 22.86^{\mathrm{a}}$ & $70.38 \pm 20.90^{\mathrm{b}}$ \\
Vessel length $(\mu \mathrm{m})$ & $375.79 \pm 100.43^{\mathrm{a}}$ & $317.52 \pm 92.54^{\mathrm{b}}$ \\
Vessel frequency $\left(\mathrm{n} / \mathrm{mm}^{2}\right)$ & $11.90 \pm 4.92^{\mathrm{a}}$ & $10.87 \pm 3.87^{\mathrm{b}}$ \\
Ray width $(\mu \mathrm{m})$ & $29.38 \pm 10.87^{\mathrm{a}}$ & $21.73 \pm 6.14^{\mathrm{b}}$ \\
Ray height $(\mu \mathrm{m})$ & $338.56 \pm 149.84^{\mathrm{b}}$ & $392.80 \pm 188.90^{\mathrm{a}}$ \\
Fibre length $(\mu \mathrm{m})$ & $889.89 \pm 171.06^{\mathrm{a}}$ & $849.92 \pm 166.35^{\mathrm{b}}$ \\
Fibre wall thickness $(\mu \mathrm{m})$ & $2.70 \pm 0.89^{\mathrm{a}}$ & $2.84 \pm 0.92^{\mathrm{a}}$ \\
\hline
\end{tabular}

to be less available. In this study, the contents of phosphorus in the transitional forests were much lower than in the mangroves, reflecting this situation.

Mangrove species are subject to extremely low water potential in the soil, because of high salinity, constraining hydraulic conductivity by the xylem (Lovelock et al., 2007). The presence of salt reduces the availability of water to the plant, known as physiological drought (Maksimovic \& Ilin, 2012). This leads to a constant trade-off between safety against cavitation and efficient hydraulic conductivity (Sobrado, 2007; (Robert, Koedam, Beeckman, \& Schmitz, 2009; Schmitz, Robert, Verheyden, Kairo, Beeckman, \& Koedam, 2008). In order to minimize effects of cavitation due to a physiological drought, it is expected that plants present narrower and shorter vessel elements in higher densities (Sobrado, 2007; Schmitz et al., 2008). However, in the present study we found a higher vessel frequency of larger diameter in the higher salinity population (mangrove area), indicating that the individuals are investing more in hydraulic conduction than safety. Schmitz, Verheyden, Beeckman, Kairo, and Koedam (2006) demonstrated the effect of salinity in vessel frequency, the higher the salinity, the higher the frequency of vessels. The authors showed that vessel diameter was less affected by salinity. Yáñez-Espinosa, Terrazas, Lopez-Mata, and Valdez-Hernandez (2004) and Robert et al. (2009) observed the same relation between salinity and higher vessel frequency for Rhizophora mucronata Lam. (Rizophoraceae). Schmitz et al. (2006) suggested that a higher vessel frequency optimizes water transport under stressful conditions (high salinity), allowing the maintenance of functional and embolized vessels proportion, as showed in other studies (Baas et al., 1983; Mauseth \& Plemons-Rodriguez, 1997).

Fiber wall thickness was also linked to water conduction, as a safety strategy in conditions of highly negative pressures within the secondary xylem, gave support to the vessels, and avoid collapse and cavitation (Hacke \& Sperry, 2001; Jacobsen, Ewers, Pratt, Paddock III, \& Davis, 2005).

Chimelo and Mattos-Filho (1988) observed wider rays in environments with larger water restrictions. Our results showed that the two populations have nearly the same amount of radial parenchyma, compensating the lower width with height and vice-versa. According to Tyree, Salleo, Nardini, Lo Gullo, and Mosca (1999), radial parenchyma is probably related to embolism repair, which is importantly fundamental for mangrove species subject to a constant physiological drought. Zheng and Martínez-Cabrera (2013) showed that rays size might vary in function: wider rays are more related to conductivity while narrower to mechanical strength.

This study showed that L. racemosa presents distinct wood anatomical features that 

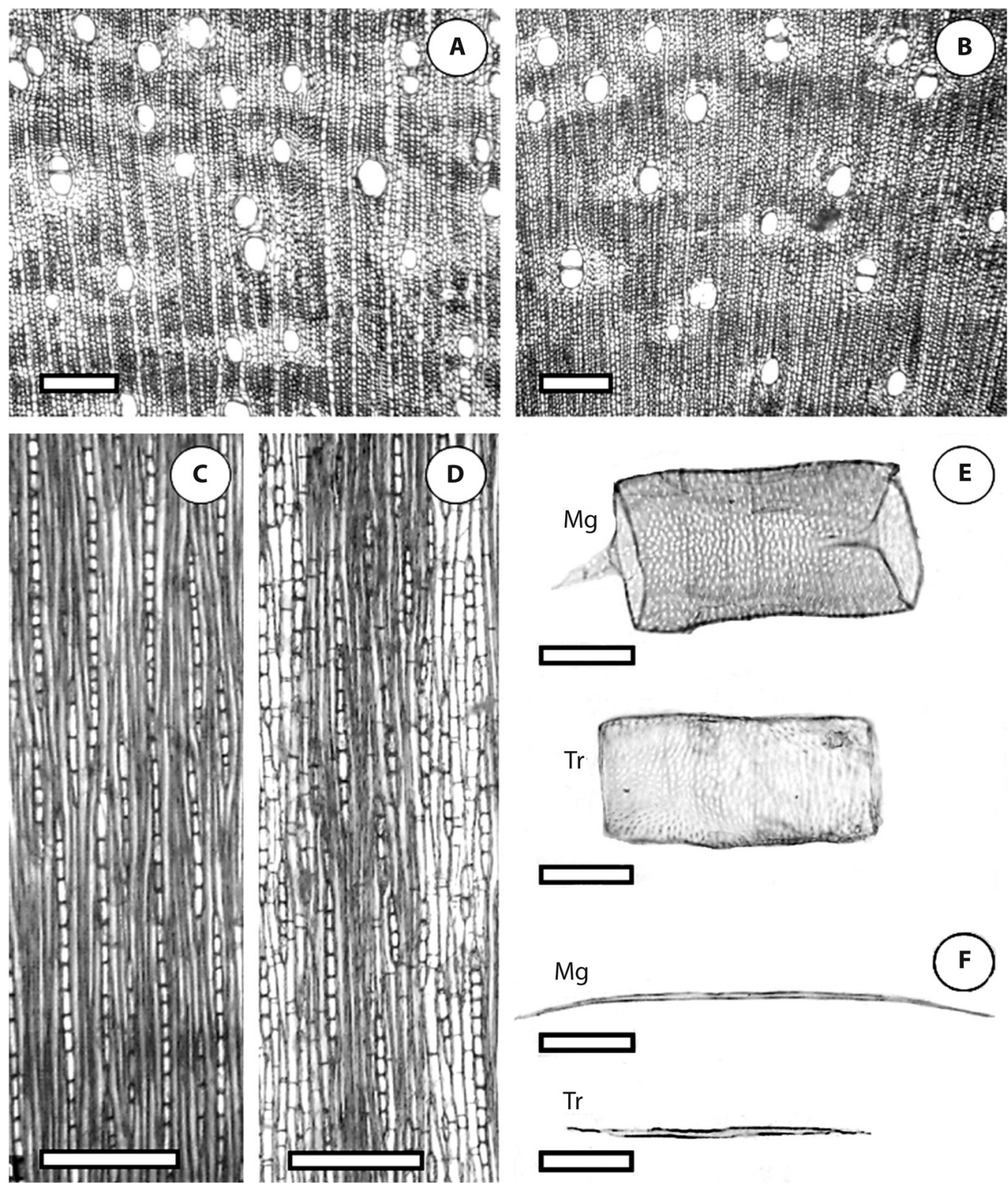

Fig. 3. Comparison of wood anatomy attributes in populations of Laguncularia racemosa (Combretaceae) in mangrove and transitional forest at the Caieira Municipal Natural Park, Joinville, Santa Catarina, Brazil. 
demonstrate the plasticity of the tissue face to soil conditions, mainly those related to hydraulic conductivity (vessels). Possibly the population of transitional area is subject to a more unstable situation, although presenting less saline soils, the very low $\mathrm{pH}$ and nutrients availability are possible factors that affect xylem structure and conductivity.

\section{RESUMEN}

Anatomía de la madera de Laguncularia racemosa (Combretaceae) en manglar y bosque de transición en el sur de Brasil. Los manglares representan un ambiente de gran heterogeneidad y baja diversidad de especies vegetales que tienen adaptaciones estructurales y fisiológicas ligadas a un ambiente de alta salinidad. Laguncularia racemosa es una especie de árbol típico en los manglares y en zonas de transición. El objetivo de este estudio fue comparar la anatomía de la madera de L. racemosa (Combretaceae) en dos bosques distintos (manglares y bosques de transición) que tienen diferentes condiciones edáficas. Para esto se obtuvieron muestras de madera y suelo en marzo 2016. Se analizaron los contenidos nutricionales de una muestra de suelo de $15 \mathrm{~cm}$ de espesor por tipo de bosque. Además, se seleccionaron cinco árboles de mangle en cada formación para el análisis de la anatomía de la madera y se tomó una muestra de cada individuo por área. Se prepararon láminas histológicas y se separaron los materiales siguiendo métodos convencionales para estudios de anatomía de la madera. El análisis del suelo mostró que en el manglar hay mayor contenido de fósforo, potasio y calcio. El suelo del bosque de transición tiene menor salinidad del agua capilar y $\mathrm{pH}$ del suelo, probablemente debido a los altos niveles de aluminio. Los atributos anatómicos difirieron entre las distintas poblaciones de bosque. En los distintos aspectos de la madera evaluados, se obtuvieron valores más altos en los individuos del manglar comparados con los de la población del bosque de transición: longitud de los elementos de los vasos $(375.79 \mu \mathrm{m})$, diámetro de los vasos tangenciales $(75.85 \mu \mathrm{m})$, frecuencia de vasos $(11.90$ $\mu \mathrm{m})$ y longitud de la fibra $(889.89 \mu \mathrm{m})$. Además, la altura de los rayos de parénquima fue mayor en las muestras del bosque de transición $(392.80 \mu \mathrm{m})$ mientras que la población de manglar presentó rayos más anchos (29.38 $\mu \mathrm{m})$. La estructura del xilema secundario en la especie estudiada aparentemente responde a los parámetros edáficos y muestra variaciones que le permiten adecuarse a las condiciones ambientales. La población del bosque de transición mostró un xilema secundario que invierte más en protección que la población del manglar.

Palabras clave: anatomía de la madera ecológica; salinidad; mangle blanco; plasticidad de la madera.

\section{REFERENCES}

Baas, P., Wheeler, E., \& Fahn, A. (1983). Some ecological trends in vessel characters. IAWA Bulletin, 4, 141159. DOI: $10.1163 / 22941932-90000407$

Ball, M. C. (1996). Comparative ecophysiology of mangrove forest and tropical lowland moist rainforest. In S. S. Mulkey, R. L. Chazdon, \& A. P. Smith (Eds.), Tropical Forest Plant Ecophysiology (pp. 461-496). New York: Chapman \& Hall. DOI: 10.1007/978-1-4613-1163-8_16

Bartz, M., Melo Jr., J. C. F., \& Larcher, L. (2015). Variação morfológica de Laguncularia racemosa (L.) C. F. Gaertn. (Combretaceae) em áreas de manguezal e de transição entre manguezal e floresta de restinga. Biotemas, 28, 21-29. DOI: $10.5007 / 2175-7925.2015 \mathrm{v} 28 \mathrm{n} 1 \mathrm{p} 21$

Bernini, E., \& Rezende, C. E. (2003). Estrutura da vegetação em florestas de mangue do estuário do Rio Paraíba do Sul, Estado do Rio de Janeiro, Brasil. Acta Brasilica Biologica, 18(3), 491-502. DOI: 10.1590/ S0102-33062004000300009

Bukatsch, F. (1972). Bemerkungen zur doppelfärbung astrablau-safranin. Mikrokosmos, 61, 33-36.

Carlquist, S. (2001). Comparative wood anatomy - systematic ecological and evolutionary aspects of dicotilidonean wood. Berlin: Springer Verlag. DOI: 10.1007/978-3-662-04578-7

Chimelo, J. P., \& Mattos-Filho, A. (1988). Observações preliminares na estrutura da madeira de cinco espécies de folhosas de diferentes locais do Brasil. São Paulo: International Union of Forest Research Organizations.

Climate-Data. (2016). Clima [online]. Available from http://pt.climate-data.org

Cosmo, N. L., Kuniyoshi, Y. S., \& Botosso, P. C. (2010). Anatomia da madeira de Sebastiania commersoniana (Baillon) Smith \& Downs (Euphorbiaceae): aspectos funcionais e ecológicos. Acta Botanica Brasilica, 24(3), 747-755. DOI: 10.1590/ S0102-33062010000300018

Empresa Brasileira de Pesquisa Agropecuária (EMBRAPA). (2013). Sistema brasileiro de classificação de solos. Brasília: EMBRAPA. Recovered from: https:// www.agrolink.com.br/downloads/sistema-brasileirode-classificacao-dos-solos2006.pdf

Epagri/Ciram. (2014). Available from: http://www.ciram. epagri.sc.gov.br

Ferreirinha, M. P. (1958). Elementos de anatomia de madeiras folhosas portuguesas. Lisboa: Memórias da Junta de Investigação do Ultramar. 
Hacke, U. G., \& Sperry, J. S. (2001). Functional and ecological xylem anatomy. Perspectives in Plant Ecology Evolution and Systematics, 4, 97-115. DOI: 10.1078/1433-8319-00017

Hossaim, M. D., \& Nuruddin, A. A. (2016). Soil and Mangrove: A review. Journal of Environmental Science and Technology, 9, 198-207. DOI: 10.3923/ jest.2016.198.207

International Association of Wood Anatomy (IAWA) Committee. (1989). List of microscopic features for hardwood identification. IAWA Bulletin, 10, 219-332. DOI: $10.1163 / 22941932-90000349$

Jacobsen, A. L., Ewers, F. W., Pratt, B., Paddock III, W. A., \& Davis, S. D. (2005). Do xylem fibers affect vessel cavitation resistance? Plant Physiology, 139, 546-556. DOI: $10.1104 /$ pp.104.058404

Johansen, D. A. (1940). Plant microtechnique. New York: McGrawHill.

Kathiresan, K., \& Bingham, B. L. (2001). Biology of mangroves and mangrove ecosystems. Advances in Marine Biology, 40, 81-251. DOI: 10.1016/ S0065-2881(01)40003-4

Kilca, R., Alberti, L., Souza, A., \& Wolff, L. (2011). Estrutura de uma floresta de mangue na Baía da Babitonga, São Francisco do Sul, SC. Ciência e Natureza, 33, 57-72. DOI: $10.5902 / 2179460 X 9362$

Kraus, J. E., \& Arduin, M. (1997). Manual básico de métodos em morfologia vegetal. Seropédica: Edur.

Krauss, K. W., Lovelock, C. E., McKee, K. L., LópezHoffman, L., Ewe, S. M. L., \& Sousa, W. P. (2008). Environmental drivers in mangrove establishment and early development: A review. Aquatic Botany, 89, 105-127. DOI: 10.1016/j.aquabot.2007.12.014

Larcher, L., Boeger, M. R. T., \& Sternberg, L. (2016). Gas exchange and isotopic signature of mangrove species in Southern Brazil. Aquatic Botany, 133, 62-69. DOI: 10.1016/j.aquabot.2016.06.001

Lima, T. M. J., \& Tognella, M. M. P. (2012). Estrutura e Função dos Manguezais: revisão conceitual. Enciclopedia Biosfera, 8, 1801-1827.

Lovelock, C. E., Feller, I. C., Ellis, J., Schwarz, A. M., Hancock, N., Nichols, P., \& Sorrell, B. (2007). Mangrove growth in New Zealand estuaries: The role of nutrient enrichment at sites with contrasting rates of sedimentation. Oecologia, 153, 633-641. DOI: 10.1007/s00442-007-0750-y

Lüttge, U. (2008). Physiological ecology of tropical plants. Berlin: Springer Science \& Business Media. DOI: 10.1007/978-3-662-03340-1

Madi, A. P. L. M., Boeger, M. R. T., \& Reissmann, C. B. (2015). Composição química do solo e das folhas e eficiência do uso de nutrientes por espécies de manguezal. Revista Brasileira de Engenharia Agrícola e Ambiental, 19, 433-438. DOI:10.1590/1807-1929/ agriambi.v19n5p433-438

Maksimovic, I., \& Ilin, Z. (2012). Effects of Salinity on Vegetable Growth and Nutrients Uptake. In T. S. Lee (Ed.), Irrigation Systems and Practices in Challenging Environments (pp. 169-190). Croatia: InTech Open. DOI: $10.5772 / 29976$

Marcati, C. R., Angyalossy-Alfonso, V., \& Benetati, L. (2001). Anatomia comparada do lenho de Copaifera langsdorffii Desf. (Leguminosae-Caesalpinoideae) de floresta e cerradão. Revista Brasileira de Botânica, 24, 311-320. DOI: 10.1590/S0100- 84042001000300010

Mauseth, J. D., \& Plemons-Rodriguez, B. J. (1997). Presence of paratracheal water storage tissue does not alter vessel characters in cactus wood. American Journal of Botany, 84, 815-822. DOI: $10.2307 / 2445817$

Naidoo, G. (2010). Ecophysiological differences between fringe and dwarf Avicennia marina mangroves. Trees, 24, 667-673. DOI: 10.1007/s00468-010-0436-7

Parida, A. K., \& Jah, B. (2010). Salt tolerance mechanisms in mangroves: A review. Trees, 24, 199-217. DOI:10.1007/s00468-010-0417-x

Pascoalini, S. S., Falqueto, A. R., \& Tognella, M. M. P. (2014). Abordagem ecofisiológica dos manguezais: uma revisão. Biotemas, 27, 1-11. DOI: $10.5007 / 2175-7925.2014 \mathrm{v} 27 \mathrm{n} 3 \mathrm{p} 1$

Prada-Gamero, R. M., Vidal-Torrado, P., \& Ferreira, T. O. (2004). Mineralogy and physical chemistry of mangrove soils from Iriri River at the Bertioga Channel. Brazilian Journal of Soil Science, 28, 233-243. DOI: 10.1590/S0100-06832004000200002

R Development Core Team. (2011). R: A Language and Environment for Statistical Computing. [online]. Available from: http://www.R-project.org

Reef, R., \& Lovelock, C. E. (2015). Regulation of water balance in mangroves. Annals of Botany, 115, 385395. DOI: $10.1093 / \mathrm{aob} / \mathrm{mcu} 174$

Robert, E. M. R., Koedam, N., Beeckman, H., \& Schmitz, N. (2009). A safe hydraulic architecture as wood anatomical explanation for the difference in distribution of the mangroves Avicennia and Rhizophora. Functional Ecology, 23, 649-65. DOI: 10.1111/j.1365-2435.2009.01551.x

Roberts, A. D. W., \& Roberts, M. D. W. (2007). Package "labdsv." R Package. version 1.3-1. Recovered from: http://ecology.msu.montana.edu/labdsv/R

Santos, T. O., Andrade, K. V. S., Santos, H. V. S., Castaneda, D. A. F. G., Santana, M. B. S., Holanda, F. S. R., \& Santos, M. J. C. (2012). Caracterização estrutural 
de bosques de mangue: Estuário do São Francisco. Scientia Plena, 8, 1-7.

Schaeffer-Novelli, Y. (1995). Manguezal: Ecossistema entre a Terra e o Mar. São Paulo: Instituto Oceanográfico-USP.

Schaeffer-Novelli, Y., Cintron-Molero, G., Adaime, R., \& Camargo, T. M. (1990). Variability of mangrove ecosystems along the Brazilian coast. Estuaries, 13, 204-218. DOI: $10.2307 / 1351590$

Schmitz, N, Robert, E. M. R., Verheyden, A., Kairo, J. G., Beeckman, H., \& Koedam, N. (2008). A patchy growth via successive and simultaneous cambia: Key to success of the most widespread mangrove species Avicennia marina? Annals of Botany, 101, 49-58. DOI: $10.1093 / \mathrm{aob} / \mathrm{mcm} 280$

Schmitz, N., Verheyden, A., Beeckman, H., Kairo, J. G., \& Koedam, N. (2006). Influence of a salinity gradiente on the vessel characters of the mangrove species Rhizophora mucronata. Annals of Botany, 98, 13211330. DOI: $10.1093 / \mathrm{aob} / \mathrm{mcl} 224$

Soares, M. L. G., Tognella, M. M. P., Cuevas, E., \& Medina, E. (2015). Photosynthetic capacity and intrinsic water-use efficiency of Rhizophora mangle at its southernmost western Atlantic range. Photosynthetica, 53, 464-470. DOI:10.1007/s11099-015-0119-0

Sobrado, M. A. (2005). Leaf characteristics and gas exchange of the mangrove Laguncularia racemosa as affected by salinity. Photosynthetica, 43, 217-221. DOI: $10.1007 / \mathrm{s} 11099-005-0036-8$

Sobrado, M. A. (2007). Relationship of water transport to anatomical features in the mangrove Laguncularia racemosa grown under contrasting salinities. New Phytologist, 173(3), 584-591. DOI: 10.1111/j.1469-8137.2006.01927.x
Tomlinson, P. B. (1986). The botany of mangroves. Cambridge: Cambridge University Press. DOI: 10.1017/ CBO9781139946575.002

Tyree, M. T., Salleo, S., Nardini, A., Lo Gullo, M. A., \& Mosca, R. (1999). Refilling of embolized vessels in young stems of laurel: do we need a new paradigm? Plant Physiology, 120, 11-22. DOI: 10.1104/ pp.120.1.11

Ukpong, I. E. (2000). Ecological classification of Nigerian mangrove using soil nutrient gradient analysis. Wetlands Ecology and Management, 8, 263-272. DOI: 10.1023/A: 1008452923256

Urrego, L. E., Molina, E. C., \& Suárez, J. A. (2014). Environmental and anthropogenic influences on the distribution, structure, and floristic composition of mangrove forests of the Gulf of Urabá (Colombian Caribbean). Aquatic Botany, 114, 42-49. DOI: 10.1016/j.aquabot.2013.12.006

Vasconcelos, M. S., Milaneze-Gutierre, M. A., \& Inada, P. (2006). Utilização de verniz vitral como meio de montagem de laminários permanentes de material vegetal. Arquivos do Mudi, 10(3), 32-35. DOI: 10.4025/arqmudi.v10i3.19986

Yáñez-Espinosa, L., Terrazas, T., Lopez-Mata, L., \& Valdez-Hernandez, J. I. (2004). Wood variation in Laguncularia racemosa and its effect on fiber quality. Wood Science and Technology, 38, 217-226. DOI: 10.1007/s00226-004-0228-6

Zheng, J., \& Martínez-Cabrera, H. I. (2013). Wood anatomical correlates with theoretical conductivity and wood density across China: evolutionary evidence of the functional differentiation of axial and radial parenchyma. Annals of Botany, 112, 927-935. DOI: $10.1093 / \mathrm{aob} / \mathrm{mct} 153$ 